\title{
Assessment of Bacterial Associations Involved in Periodontal Disease Using Crevicular Fluid
}

\author{
ALEXANDRA CORNELIA TEODORESCU1,2, SILVIA TESLARU ${ }^{1 *}$, SORINA MIHAELA SOLOMON ${ }^{1 *}$, LIVIU ZETU1 ${ }^{1}$, IONUT LUCHIAN ${ }^{1}$, \\ IOANA-ANDREEA SIOUSTIS ${ }^{1,2}$, MARIA ALEXANDRA MARTU'1, BOGDAN VASILIU ${ }^{1,2}$, SILVIA MARTU ${ }^{1}$ \\ ${ }^{1}$ Grigore T. Popa Univeristy of Medicine and Pharmacy lasi, Faculty of Dental Medicine, 16 Universitatii Str., 700115, Romania \\ ${ }^{2}$ Grigore T. Popa Univeristy of Medicine and Pharmacy, Iasi, 16 Universitatii Str., 700115, Romania
}

\begin{abstract}
Generalized aggressive periodontitis (GAP) and severe chronic periodontitis (SCP) are two different clinical entities for which the differential diagnosis can become difficult to establish especially in patients over 35 years of age. The aim of this study was to determine the bacterial subgingival profiles for these two types of periodontitis and to highlight the possible bacterial associations that are characteristic to each clinical form, thus making the differential diagnosis easier for the general dental practitioner.
\end{abstract}

Keywords: aggressive periodontitis, chronic periodontitis, bacterial profiles, Real-Time PCR

Periodontitis is an inflammatory, multifactorial disease that is characterised by the destruction of the alveolar bone and by attachment loss (periodontal pockets or/and gingival recessions) [1]. It is well known that the onset and progression of periodontitis is tightly linked to the presence of periodontal pathogenic bacteria [2], organised as a biofilm. This subgingival biofilm is a complex and very dynamic bacterial system which contains hundreds of different bacterial species [3,4], amongst which only a small part are known as being pathogens to the periodontium.

In 1988, after analysing a great number of crevicular fluid samples collected from healthy and periodontitis affected patients, Socransky divided the bacteria he found subgingivaly in bacterial complexes [5], depending on their characteristics. Among these bacteria, Aggregatibacter actinomycetemcomitans $(\mathrm{Aa})$ is one of the most studied and considered to be linked to the aggressive periodontitis cases [6]. More than that, the presence of Porphyromonas gingivalis (Pg), Tanerella forsythia (Tf) and Treponema denticola (Td), from the red complex [6], is considered to be correlated with chronic periodontitis [7-9]. In general, periodontitis is associated with a high proportion of gramnegative anaerobic microorganisms $[10,11]$ and even viruses are believed to be involved in its pathogenesis $[12,13]$

In this inflammation and periodontal destruction context, the bacteria are not the only one involved, but also the immunologic host response. Through the immune system, the bacteria have an indirect inflammatory effect [14-16]. A strong influence is being made by the genetic factor, environmental and behaviour factors that influence the host immune response, the bone and connective tissue metabolism.

In 1999, Gary Armitage contributes to the publishing of a new classification for periodontal diseases and conditions [17], mentioning the existence of 3 different forms of periodontitis: chronic, aggressive and necrotising. The aggressive and chronic periodontitis have some in common characteristics such as: they are both infectious diseases that affect defence impaired hosts as a response to the bacteria attack and they both exhibit the same signs of inflammation and tissue destruction [18], but more important are the differentiating characteristics.

The chronic periodontitis is more frequent in adults, its periodontal destruction is directly correlated with the biofilm and calculus deposits, the progression rate is slow to moderate and the patient can also present local and general risk factors (systemic diseases) [19]. The localised form affects under $30 \%$ of the remaining teeth and the generalised form affects more than $30 \%$ of them [17]. The bone resorption is mainly horizontal for this type of periodontitis.

On the other hand, aggressive periodontitis affects clinically healthy and young patients, the attachment loss and alveolar bone resorption are much faster, the genetic factor has a great importance, the biofilm deposits are not correlated with the severity of the periodontal destruction, great quantities of $\mathrm{Aa}$ and $\mathrm{Pg}$ can be found and also phagocyte anomalies [20]. The generalized form implies that 3 or more teeth, other than incisors and first molars, are affected by the attachment loss and the alveolar bone destruction has a mixt appearance, combining vertical and horizontal defects.

\section{Experimental part}

This study was made on 54 patients, with ages between 20 and 56 years old, between October 2016 and January 2018. These patients were examined at the Periodontal Department of the Dental Medicine Faculty of the Grigore T. Popa University of Medicine and Pharmacy from lasi and in a private practice in the same city. The aim of this study was to determine the bacterial subgingival profiles for these two types of periodontitis and to highlight the possible bacterial associations that are characteristic to each clinical form, thus making the differential diagnosis easier for the general dental practitioner.

For the patients to be included in this study, they had to have the ages betw een 18 and 58 years old and to present a form of periodontitis, be it generalised aggressive or severe chronic. The exclusion criteria consisted in: periodontal therapy 6 months prior to the beginning of the study and systemic antibiotic therapy 3 months before, pregnant or breastfeeding women, important systemic diseases such as leukaemia, malignant tumours, recent acute cardiac episodes, anticoagulant therapy, ongoing bisphosphonates therapy or in the 12 months prior to the beginning of the study. All patients included in the study read and signed a Consent Form.

After a thorough periodontal clinical exam, the patients were divided into 2 groups: the GAP and the SCP. For each patient we selected 5 teeth, the 5 most affected sites (the deepest periodontal pockets or the highest attachment loss). One at a time, each site was isolated with sterile 
cotton rolls and the saliva was removed the surface of the teeth with the help of air spray. Using sterile paper points, crevicular fluid filled with bacteria was collected from each selected periodontal pocket. For this stage we used the PET kits made by MIP Pharma GmbH. The paper points were left in place for $20 \mathrm{~s}$ and then put into a transport Ependorf tube and shipped to the laboratory in Germany (fig. 1, 2). There, the crevicular fluid samples were analysed as cumulated sample through a Real-Time PCR technique (polymerase chain reaction).

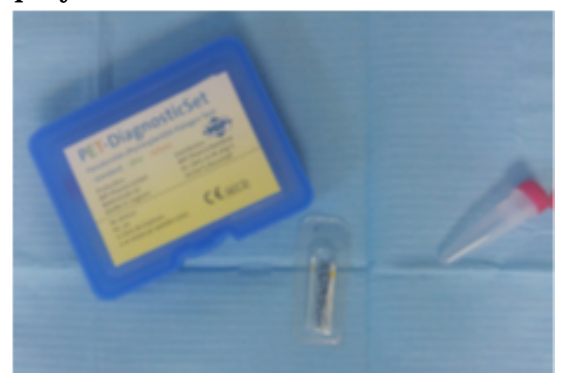

Fig. 1. The PET Kit from MIP Pharma

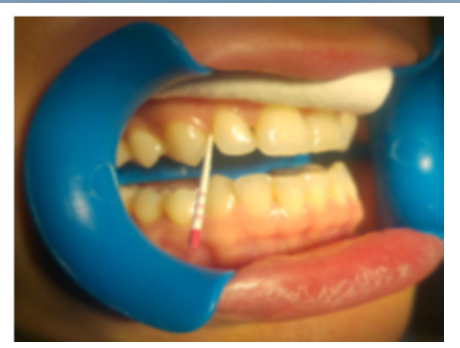

Fig. 2. Collection of crevicular fluid

The working principle for the Real-Time PCR consists in DNA amplification and quantification of the PCR product in one stage through fluorescence. Thus, fluorescence is proportional with a number of DNA amplifications. The applications of Real-Time-PCR in medicine and biology are the detection and quantification of bacterial and viral pathogens, genotyping, the quantification of genic expression and the analysis of DNA deterioration. The manufacturer presents numerous advantages for this type of Real-Time-PCR testing: accurate quantification of periodontal pathogens, high reproducibility, high specificity, high sensitivity, quick detection (short cycles of 1-1,5 hours) and low risk of contamination [21]. The PET Plus test shows the presence and quantification of 9 periodontal pathogens in each examined sample: Aggregatibacter actinomycetemcomitans ( $\mathrm{Aa}$ ), Porphyromonas gingivalis (Pg), Treponema denticola (Td), Tannerella forsythia (Tf), Prevotella intermedia (Pi), Peptostreptoccocus micros $(\mathrm{Pm})$, Fusobacterium nucealtum (Fn), Eubacterium nodatum (En) and Capnocytophaga gingivalis (Cg).

\section{Results and discussions}

The statistics were made using SPSS 20.0 program. We used Person Chi-Square, t-student, the non-parametric

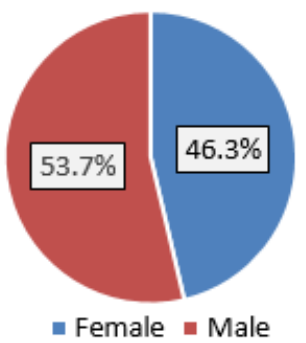

Fig. 3. The sex

distribution for the entire study group

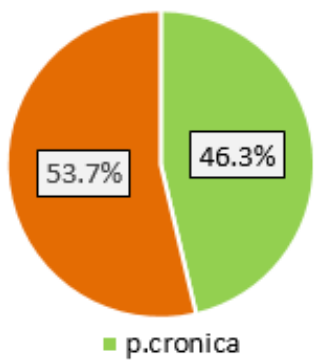

Fig. 4. The diagnosis distribution for the study groups
Mann-Whitney and Kruskal-Wallis tests. We considered a statistically significant value of $p<0.05$.

The study was performed on 54 patients, 29 males and 25 females, from which 29 with GAP and 25 with SPC. The ages of the study participants ranged between 20 and 56 years, with a mean value of $38.78 \pm 9.189$ years.

In order to compare the age mean values between the two study groups we used the t-test. It is obvious that the mean age value was significantly low er for the GAP patients (35.31 \pm 1.468 years) than the mean value for the SCP group (42.8 \pm 1.813 years) with a value of $p=0.02$.

The first stage was to analyse the prevalence of each periodontal pathogen for the two study groups (GAP and PCS) individually and by comparison as it is shown in the figure 5 .

For the SCP study group, 4 of the 9 periodontal pathogens had a very high prevalence of over $90 \%: \mathrm{Pg}, \mathrm{Td}, \mathrm{Pm}$ and $\mathrm{Cg}$. The other 5 bacteria were present but with lower prevalences: Aa 16\%, Fn 32\% and Ee 44\%. When we analysed the GAP group we observed that Td was present in $100 \%$ of the patients and other 4 pathogens were highly prevalent (over $90 \%$ ): $\mathrm{Pg}, \mathrm{Tf}, \mathrm{Pm}$ and $\mathrm{Cg}$. The only bacteria with a lower prevalence (under $50 \%$ ) were Aa.

When we compared the two study groups it was clear that $\mathrm{Aa}$, a bacteria correlated usually with aggressive periodontitis forms, was not only present in the GAP group (11 patients) but also in 4 cases of SCP, without a statistically significant difference. More so, all of the 9 periodontal pathogens showed a higher prevalence for the GAP group, significantly higher for $\mathrm{Fn}(p=0.007)$ and $\mathrm{En}$ $(p=0.007)$.

A second step was analysing the quantities of each periodontal pathogen. We noticed that for the SCP group the bacteria with higher mean values were Td $\left(7.08 \times 10^{5} \pm 1.06 \times 10^{6}\right)$, $\operatorname{Tf}\left(5.33 \times 10^{5} \pm 1.16 \times 10^{6}\right)$ and $\mathrm{Pg}$ $\left(4.35 \times 10^{5} \pm 5.35 \times 10^{5}\right)$ and with lower mean values were Aa $\left(2.59 \times 10^{3} \pm 2.89 \times 10^{3}\right)$ and $\mathrm{En}\left(3.02 \times 10^{4} \pm 5.92 \times 10^{4}\right)$, as shown in table I.

For the GAP study group we found that the bacteria with higher mean counts were $\mathrm{Pg}\left(7.34 \times 10^{5} \pm 8.86 \times 10^{5}\right)$, Pi $\left(6.65 \times 10^{5} \pm 8.23 \times 10^{5}\right)$ and $\mathrm{Td}\left(5.56 \times 10^{5} \pm 5.87 \times 10^{5}\right)$, as for

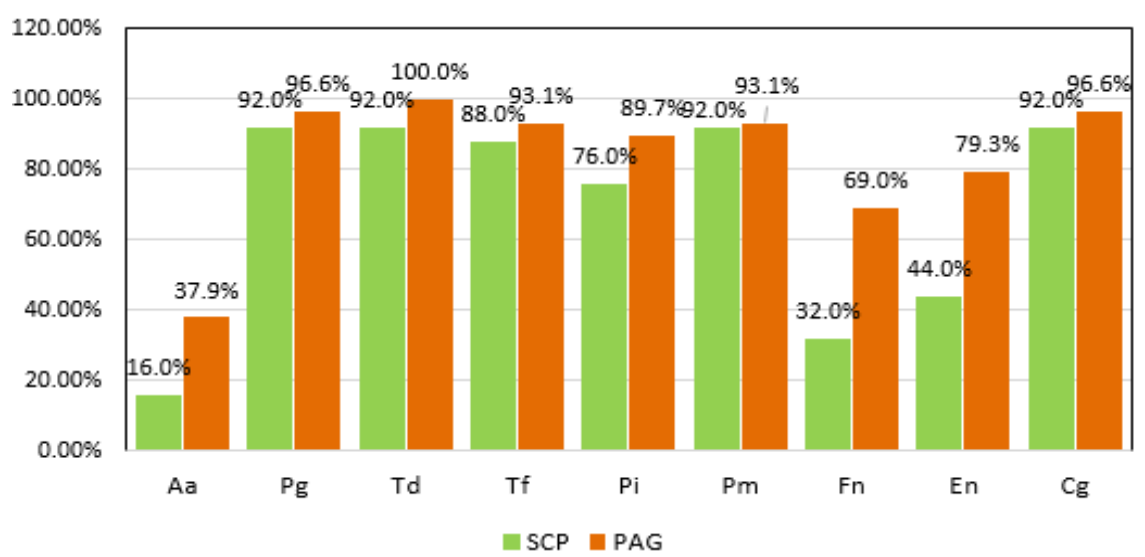

Fig. 5. The compared prevalence of the 9 periodontal pathogens for the 2 study groups 
the bacteria with lower mean counts we found En $\left(9.3 \times 10^{3} \pm 1.15 \times 10^{4}\right)$ and $A a\left(8.57 \times 10^{4} \pm 8.25 \times 10^{4}\right)$, as shown in table 2.

We used the Mann-Whitney non parametric test to highlight the possible differences between the two study groups and it was obvious that there were statistically significant differences> the GAP patients exceeded higher quantities of $\mathrm{Aa}$ and $\mathrm{Pg}$ as it is seen in table 3 .

After analysing the results we noticed that the mean age for the GAP patients was significantly lower ( $35.31 \pm 7.9$ years) than for the SCP patients ( $42.8 \pm 9$ years) concordantly with the literature data that aggressive periodontitis has its onset early in life, before the age of 25 [22], and so the diagnosis is also made earlier comparing to the chronic periodontitis cases that are usually visible after the age of 35 .

From a pathogen point of view, the prevalence of $A a$ was much higher in the GAP group (11 patients) compared to the SCP group ( 4 patients), without having a statistically significance. Our results were similar to those of another study, made on 260 patients of which 75 with GAP and 185 with $C P$, that found no significant differences concerning the prevalence of $\mathrm{Aa}$, but without analysing the quantity of bacteria in the collected samples [10]. Other studies along the way correlated the presence of this periodontal pathogen with either aggressive periodontitis [23-26] or with chronic forms $[27,28]$.

$\mathrm{Pg}$ had a high prevalence in both of the study groups (92\% in SCP versus $96,6 \%$ in GAP) without a statistical difference between the tw 0 . Other studies reported similar results, saying that $\mathrm{Pg}$ is not a bacterium with a high differential diagnostic ability, because it can be found in both forms of periodontitis [29,30]. More so, Pg could be a opportunistic pathogen that causes periodontal disease only in favourable conditions [31]. Heller et al., in a study published in 2012 compared the microbial profiles of GAP and CP (chronic periodontitis) and found a significant correlation between the prevalence of $\mathrm{Pg}$ and the chronic periodontitis group [10]. Contrary to these findings, other studies have found that higher quantities of $\mathrm{Pg}$ are significantly correlated with cases of aggressive periodontitis [32,33]. The same correlation was found in the present study where higher counts of $\mathrm{Aa}$ and Pg were found in the GAP group.

In the present study we found significant differences in the prevalence of $\mathrm{Fn}$ and $\mathrm{En}$, which were correlated with the GAP group. These results are partially sustained by our previous preliminary study, made on 20 patients, that found a qualitative and quantitative correlation of $\mathrm{Fn}$ with the GAP group [34].

$\mathrm{Fn}$ is a Gram negative, anaerobe microorganism with a good adhesion capacity within the oral biofilm, that has got a lot of attention from medical specialists and researchers because he is believed to be an opportunistic commensal, not only for the periodontal disease [35]. It is one of the most frequent bacterial species in the oral cavity of healthy and periodontal impaired patients, be ita simple form of gingivitis or a chronic or aggressive periodontitis [36-40].

Fn plays an important role in the formation and maturation of dental biofilm and it is the microorganism that ties the commensals that attach initially and the pathogens that are later colonisers in the dental biofilm. Additionally, there are researchers who found that $\mathrm{Fn}$ is

\begin{tabular}{|c|c|c|c|c|c|c|}
\hline PCS group & $\mathbf{N}$ & Mean & $\begin{array}{l}\text { Standard } \\
\text { Error of the } \\
\text { Mean }\end{array}$ & $\begin{array}{l}\text { Standard } \\
\text { Deviation }\end{array}$ & Minimum & Maximum \\
\hline $\begin{array}{l}\text { Total bacterial } \\
\text { count }\end{array}$ & 25 & 260974800 & 64433893.7 & 322169469 & 470000 & 1400000000 \\
\hline $\mathrm{Aa}$ & 4 & 2595.75 & 1447.562 & 2895.123 & 83 & 6700 \\
\hline $\mathrm{Pg}$ & 23 & 435808.7 & 111601.065 & 535219.905 & 1600 & 2100000 \\
\hline Td & 23 & 708533.91 & 221750.592 & 1063478.48 & 480 & 3700000 \\
\hline Tf & 22 & 533672.73 & 248795.964 & 1166956.51 & 1800 & 4800000 \\
\hline $\mathrm{Pi}$ & 19 & 318248.95 & 84409.245 & 367931.368 & 230 & 1300000 \\
\hline $\mathrm{Pm}$ & 23 & 91036.09 & 33279.846 & 159604.535 & 330 & 600000 \\
\hline Fn & 8 & 167802.5 & 66181.74 & 187190.229 & 120 & 490000 \\
\hline En & 11 & 30282.73 & 17861.572 & 59240.133 & 400 & 200000 \\
\hline $\mathrm{Cg}$ & 23 & 356043.48 & 128397.38 & 615772.204 & 11000 & 2600000 \\
\hline GAP group & $\mathrm{N}$ & Mean & $\begin{array}{l}\text { Standard } \\
\text { Error of the } \\
\text { Mean }\end{array}$ & $\begin{array}{l}\text { Standard } \\
\text { Deviation }\end{array}$ & Minimum & Maximum \\
\hline $\begin{array}{l}\text { Total bacterial } \\
\text { count }\end{array}$ & 29 & 427965517 & 109254567 & 588353847 & 27000000 & 2100000000 \\
\hline $\mathrm{Aa}$ & 11 & 85772.73 & 24885.005 & 82534.224 & 1400 & 220000 \\
\hline $\mathrm{Pg}$ & 28 & 734500.00 & 167492.806 & 886288.62 & 29000 & 4000000 \\
\hline Td & 29 & 556965.52 & 109018.929 & 587084.898 & 25000 & 3100000 \\
\hline Tf & 27 & 339592.59 & 89066.163 & 462801.358 & 12000 & 1700000 \\
\hline $\mathrm{Pi}$ & 26 & 665957.69 & 163232.353 & 832324.955 & 6900 & 3700000 \\
\hline $\mathrm{Pm}$ & 27 & 122085.19 & 41664.588 & 216495.551 & 1800 & 1100000 \\
\hline Fn & 20 & 191731.50 & 59058.019 & 264115.491 & 260 & 850000 \\
\hline En & 23 & 9306.52 & 2407.245 & 11544.743 & 170 & 34000 \\
\hline $\mathrm{Cg}$ & 28 & 265285.71 & 77742.977 & 411377.168 & 2000 & 1700000 \\
\hline
\end{tabular}

Table 1

THE TOTAL BACTERIAL COUNT AND THE QUANTITATIVE VALUES OF THE 9 PERIODONTAL PATHOGEN IN THE PAG GROUP

Table 2

THE TOTAL BACTERIAL COUNT AND THE QUANTITATIVE VALUES OF THE 9 PERIODONTAL PATHOGEN IN THE SCP GROUP 


\begin{tabular}{|c|c|c|c|c|c|c|c|c|c|}
\hline & \multicolumn{3}{|c|}{ SCP group } & \multicolumn{3}{|c|}{ GAP group } & \multirow{2}{*}{$\begin{array}{l}\text { Mann- } \\
\text { Whitney } \\
\text { U }\end{array}$} & \multirow[t]{2}{*}{ p-value } & \multirow{12}{*}{$\begin{array}{c}\text { Table } 3 \\
\text { THE TOTAL BACTERIAL } \\
\text { COUNTS AND COMPARED } \\
\text { QUANTITATIVE VALUES FOR } \\
\text { THE } 9 \text { PERIODONTAL } \\
\text { PATHOGENS IN THE TWO } \\
\text { STUDY GROUPS }\end{array}$} \\
\hline & $\mathrm{N}$ & $\begin{array}{l}\text { Mean } \\
\text { Rank }\end{array}$ & $\begin{array}{l}\text { The Sum } \\
\text { of Ranks }\end{array}$ & $\bar{N}$ & $\begin{array}{l}\text { Mean } \\
\text { Rank }\end{array}$ & $\begin{array}{l}\text { The Sum } \\
\text { of Ranks }\end{array}$ & & & \\
\hline $\begin{array}{l}\text { Total } \\
\text { bacterial } \\
\text { count }\end{array}$ & 25 & 25.46 & 636.50 & 29 & 29.26 & 848.50 & 311.500 & 0.376 & \\
\hline $\mathbf{A a}$ & 4 & 3.75 & 15.00 & 11 & 9.55 & 105.00 & $5.000^{--}$ & 0.026 & \\
\hline $\mathrm{Pg}$ & 23 & 21.28 & 489.50 & 28 & 29.88 & 836.50 & 213.500 & $0.040^{-}$ & \\
\hline $\mathrm{Td}$ & 23 & 23.96 & 551.00 & 29 & 28.52 & 827.00 & 275.000 & 0.281 & \\
\hline Tf & 22 & 23.30 & 512.50 & 27 & 26.39 & 712.50 & 259.500 & $0.451^{-}$ & \\
\hline $\mathbf{P i}$ & 19 & 18.79 & 357.00 & 26 & 26.08 & 678.00 & $167.000^{-}$ & $0.066^{-}$ & \\
\hline $\mathrm{Pm}$ & 23 & 22.61 & 520.00 & 27 & 27.96 & 755.00 & 244.000 & 0.195 & \\
\hline Fn & 8 & 15.00 & 120.00 & 20 & 14.30 & 286.00 & $76.000^{-}$ & $0.839^{-}$ & \\
\hline En & 11 & 18.50 & 203.50 & 23 & 17.02 & 391.50 & 115.500 & $0.685^{\circ}$ & \\
\hline $\mathrm{Cg}$ & 23 & 26.48 & 609.00 & 28 & 25.61 & 717.00 & 311.000 & $0.835^{-}$ & \\
\hline
\end{tabular}

capable of sustaining the growth of Pg in oxygen filled and CO2 lacking environments, where Pg would not be able to normally survive [41]. The results of our study confirm this idea, considering the fact that the GAP group showed a significantly higher prevalence of $\mathrm{Fn}$ and higher quantities of $\mathrm{Pg}$, suggesting that there is a strong correlation between the two periodontal pathogens.

Concerning the significantly higher presence of En in the GAP group reported in our study, it comes to support the conclusions of other studies that found a strong correlation between these bacteria and aggressive forms of periodontal disease [24]. En is an asaccharolytic, anaerobic and nonreactive bacterium that grows with great difficulty on culture environments [42], but which seems to become more and more abundant once the aggressive periodontitis patient grows older.

Taking into account the mixt results shown in the recent studies and their limited numbers comparing subgingival microbial profiles of aggressive and chronic periodontitis, Real-Time PCR testing can be very useful, using either crevicular fluid or saliva [43]. This type of analysis will uncover the periodontitis cases, chronic or aggressive, that harbour bacteria such as $\mathrm{Aa}$ and $\mathrm{Pg}$. The presence of either of the two periodontal pathogens in high numbers, above the pathogenic threshold, justifies the use of systemic antibiotics during MINST (minimal invasive non-surgical therapy). Using this type of testing for patients with important periodontal damage, periodontists and general dentists will be able to recommend a specific antibiotic therapy, and not an empirical one, thus limiting the global antibiotics usage and lowering the risk of bacterial resistances.

Our study has its own limitations. It has been made on a small group of 54 Caucasian patients. The general prevalence of aggressive periodontitis is pretty low, affecting more the African-Americans. It is believed that its prevalence varies from $0,1 \%$ in Central and Northern Europe, to 2,6\% for the black population in Northern America and to 1-5\% for the African populations [44]. Unfortunately, there are no available data regarding the prevalence of chronic or aggressive periodontitis for the Romanian population. For the enrolment in this study, one of the exclusion criteria was a systemic antibiotic therapy 3 months prior to the beginning of the study. This limitation reduced furthermore the number of patients available to participate in such a study because, in Romania, a lot of people take frequently as self-medication antibiotics for different types of systemic diseases, colds and flues.

Another limitation for our study was the use of the commercial test PET Plus from MIP Pharma GmbH, a test which determines the presence and numbers of only 9 periodontal pathogens. More studies are necessary in order to highlight the presence of other periodontal pathogens implicated in chronic and aggressive periodontitis, studies which should be made on larger study groups. These will make possible the discovery of new periodontal bacteria with a key role in differential diagnosis and more precise results.

\section{Conclusions}

The present study shows that there is a correlation between the presence of two periodontal pathogens, Fn and En, and a PAG diagnosis. Additionally, the quantitative evaluation of the 9 periodontal pathogens has show $n$ higher number of bacteria for PAG patients compared to SCP patients. Our study clearly emphasized that $A a$ and $P g$, the main periodontal pathogens, had significantly higher values in the PAG group. The individualised determination of periodontal pathogens, using any method available and especially RT PCR, helps steering a systemic antibiotic therapy and limits the self-medication and the possibility of developing bacterial resistances.

\section{References}

1.COCHRAN, D.L., J. Periodontol., 79, no. 8s, 2008, p. 1569-76.

2.*** J Periodontol., 70, no. 4, 1999, p.457-70.

3.DENG, Z.L., SZAFRAÑSKI, S.P., JAREK, M., et al., Sci. Rep., 7, no. 1, 2017, p. 1-13.

4.PASTER, B.J ., OLSEN, I., AAS, J.A., DEWHIRST, F.E., Periodontol 2000, 42, no. 1, 2006, p. 80-7.

5.SOCRANSKY, S.S., HAFFAJ EE, A.D., CUGINI, M.A., SMITH, C., KENT, R.L. JR., J Clin Periodontol, 25, no. 2, 1998, p.134-44.

6.SANCHEZ, G.A., ACQUIER, A.B., COUTO, A.D., ET AL., Microb Pathog., 82, 2015, p.31-6.

7.KUMAR, P., GRIFFEN, A., BARTON, J., ET AL., J Dental Res., 82, no. 5, 2003, p.338-44.

8.SOCRANSKY, S.S., HAFFAJ EE, A.D., Periodontol 2000, 38, no. 1, 2005, p.135-87.

9.HELLER, D.C.A., SILVA-BOGHOSSIAN, C.M., SOUTO, R.M.D., COLOMBO, A.P.V., Arch Oral Biol., 57, no. 7, 2012, p.973-80.

10.ROSENSTEIN, E.D., GREENWALD, R.A., KUSHNER, L.J ., WEISSMANN, G., Inflammation, 28, 2004, p311-318. 
11.MARTU, M.A., SOLOMON, S.M., SUFARU, I.G., ET AL., Rev. Chim. (Bucharest), 68, no. 8, 2017, p.1946-1949.

12.SOLOMON, S.M., FILIOREANU, A.M., STELEA, C.G., ET AL., Rev. Chim (Bucharest), 69, no. 2, 2018, p.507-510.

13.POPA, C., STELEA, C.G., FILIOREANU, A.M., ET AL., Rev. Chim. (Bucharest), 68, no. 11, 2017, p.2673-2675

14.GENCO, R.J , J Periodontol, 63, no. 4s, 1992, p.338-55.

15.LARSEN, T., FIEHN, N.E, APMIS, 125, no. 4, 2017, p.376-84.

16.VEISA, G., DONCIU, M., SEGAL, L., HURJUI, L,, NISTOR, I., URSARESCU, I., MARTU, S., BURLEA, L., SOLOMON, S. Rev. Chim. (Bucharest), 67, no.1, 2016, p.103-105

17.ARMITAGE, G.C., Ann Periodontol, 4, 1999, p.1-6.

18.ARMITAGE, G.C., CULLINAN, M.P., Periodontol 2000, 53, no. 1, 2010, p.12-27.

19.FLEMMIG, T.F., Ann Periodontol, 4, 1999, p.38.

20.ARMITAGE, G.C., Ann Periodontol, 4, 1999, p.53.

21. ZENTILIN, L., GIACCA, M., Nature Protocols, 2, 2007, p.20922104.

22.ALBANDAR, J.M., Periodontol 2000, 65, no. 1, 2014, p.13-26.

23.FINE, D.H., MARKOWITZ, K., FURGANG, D. ET AL., J Clin Microbiol., 45, no. 12, 2007, p.3859-69.

24.ELABDEEN, H.R.Z., MUSTAFA, M., HASTURK, H., ET AL., J Periodontal Res., 50, no. 5, 2014, p.674-82.

25.SÁNCHEZ, G.A., ACQUIER, A.B., COUTO, A.D., BUSCH, L., MENDEZ, C.F., Microb Pathog., 82, 2015, p.31-6.

26.MARTU, I., GORIUC, A., MARTU, M.A., ET AL., Rev Chim (Bucharest), 68, no. 10, 2017, p.2407-12.

27.CORTELLI, J .R., CORTELLI, S.C., JORDAN, S., ET AL., J Clin Periodontol., 32, no. 8, 2005, p.860-6.

28.LEE, J.W., CHOI, B.K., YOO, Y.J ., ET AL., J Periodontol., 74, no. 9, 2003, p.1329-35.
29.TOMITA, S., KOMIYA-ITO, A., IMAMURA, K., ET AL., Microb Pathog., 61-62, 2013, p.11-5.

30.BENRACHADI, L., BOUZIANE, A., AZZIMAN, Z., ET AL., Med Mal Infect., 42, no. 12, 2012, p.599-602.

31.GRIFFEN, A.L., BECKER, M.R., LYONS, S.R., ET AL., J Clin Microbiol., 36, no. 11, 1998, p.3239-42.

32.OETTINGER-BARAK, O., SELA, M.N., SPRECHER, H., MACHTEI, E.E., Aust Dent J ., 59, no. 2, 2014, p.165-71.

33.CHAHBOUN, H., ARNAU, M.M., HERRERA, D., ET AL., BMC Oral Health, 15, 2015, p.25.

34.TEODORESCU, A.C., ZETU, L., TESLARU, S., ET AL., Int J Med Dent., 7, no. 2, 2017, p.135-9.

35.HAN, Y.W., Curr Opin Microbiol., 23, 2015, p.141-7.

36.MOORE, W.E., MOORE, L.V., Periodontol 2000, 5, 1994, p.66-77.

37.GRIFFEN, A.L., BEALL, C.J., CAMPBELL, J.H., ET AL., ISME J., 6, no. 6, 2012, p.1176-85.

38.LOOZEN, G., OZCELIK, O., BOON, N., ET AL., J Clin Periodontol., 41, no. 1, 2014, p.1-10.

39.FENG, X., ZHU, L., XU, L., ET AL., Arch Oral Biol., 60, no. 3, 2015, p.400-7.

40.YANG, N.Y., ZHANG, Q., LI, J.L., ET AL., IntJ Paediatr Dent., 24, no. 3, 2014, p. 226-33.

41.DIAZ, P.I., ZILM, P.S., ROGERS, A.H., Microbiology, 148, Pt 2, 2002, p.467-72.

42.ARORA, N., MISHRA, A., CHUGH, S., J Indian Soc Periodontol., 18, no. 1, 2014, p.9-13.

43.SOLOMON, S.M., MATEI, M., BADESCU, A.C., ET AL., Rev. Chim. (Bucharest), 66, no. 12, 2015, p.2101-2103.

44.SUSIN, C., HAAS, A.N., ALBANDAR, J .M., Periodontol 2000, 65, no. 1,2014, p. 27-45.

$\overline{\text { Manuscript received: } 19.12 .2018}$ 